\title{
Hubungan Pengetahuan Dengan Sikap Ibu Tentang Imunisasi Hepatitis B Pada Bayi (0-11 Bulan)
}

\author{
Arifah Septiane Mukti \\ Program Studi Kebidanan, Universitas Galuh Ciamis \\ e-mail : arifah_mukti@yahoo.com
}

(Diterima 27-02-2019; disetujui 25-04-2019; dipublish 09-05-2019)

\begin{abstract}
Abstrak
Infeksi hepatitis B merupakan problem kesehatan masyarakat di dunia. Di Indonesia setiap tahun ada $36 \%$ bayi yang belum mendapatkan imunisasi, sehingga dalam 5 tahun menjadi 2 juta anak yang belum mendapatkan imunisasi hepatitis B. Banyak faktor yang menyebabkan masyarakat enggan mengimunisasikan bayinya, salah satunya adalah faktor predisposisi yaitu pengetahuan.Penelitian ini bertujuan untuk mengetahui hubungan antara tingkat pengetahuan ibu tentang imunisasi hepatitis B dengan sikap ibu mengimunisasikan bayinya di wilayah kerja Puskesmas Panumbangan Kecamatan Panumbangan. Rancangan penelitian yang digunakan survei lapangan yang bersifat korelasi dengan pendekatan cross-sectional. Sampel sebanyak 84 responden ibu yang memiliki bayi 1 tahun. Teknik sampling yang digunakan pada penelitian ini adalah stratified random sampling. Tingkat pengetahuan ibu tentang pengertian imunisasi hepatitis B paling banyak kategori rendah $37(44,0 \%)$ responden. Sikap ibu mengimunisasikan bayinya ke Puskesmas paling banyak sikap negatif $46(54,8 \%)$ responden. Terdapat hubungan antara pengetahuan ibu tentang imunisasi hepatitis B dengan sikap ibu mengimunisasikan bayinya di Kecamatan Panumbangan (nilai $\mathrm{p}=0.029<\alpha=0,05$ ). Kesimpulan dari penelitian ini adalah tingkat pengetahuan ibu tentang imunisasi hepatitis B berhubungan dengan sikap mengimunisasikan bayinya di wilayah kerja Puskesmas Kecamatan Panumbangan.
\end{abstract}

Kata Kunci : Pengetahuan, Sikap, Imunisasi Hepatitis B

Kepustakaan : $21(2000-2012)$

\begin{abstract}
Hepatitis B infection is a public health problem in the world. In Indonesia every year there are $36 \%$ of infants who have not received immunization, so in 5 years there are 2 million children who have not received hepatitis $B$ immunization. Many factors cause people to be reluctant to immunize their babies, one of which is predisposing factors namely knowledge. This study aims to find out the relationship between the level of knowledge of mothers about hepatitis B immunization and the attitude of mothers to immunize their babies in the work area of Panumbangan Health Center, Panumbangan District. The study design used a field survey that was correlated with a cross-sectional approach. The sample is 84 respondents of mothers who have 1-year babies. The sampling technique used in this study is stratified random sampling. The level of knowledge of mothers about the notion of hepatitis B immunization is at most low categories 37 (44.0\%) respondents. The attitude of mothers to believe their babies to the Puskesmas was the most negative attitude 46 (54.8\%) respondents. There is a relationship between a mother's knowledge about hepatitis $B$ immunization and the attitude of mothers to immunize their babies in Panumbangan Subdistrict (value $p=0.029<\alpha=0.05$ ). The conclusion of this study is the level of knowledge of mothers about hepatitis B immunization-related to the attitude of immunizing their babies in the work area of Panumbangan District Health Center.
\end{abstract}

Keywords: Knowledge, Attitude, Hepatitis B Immunization

Literature: 21 (2000-2012) 


\section{PENDAHULUAN}

Hepatitis B adalah suatu penyakit hati yang disebabkan oleh virus hepatitis B (VHB). Hepatitis B adalah penyakit yang dapat merusak hati dan dapat berlangsung lama dan menjadi berat, pengobatan hepatitis B semakin lama semakin dikembangkan oleh berbagai negara dan sebagai salah satu perhatian kesehatan dunia. ${ }^{1}$

Infeksi hepatitis B merupakan problem kesehatan masyarakat di dunia, diperkirakan ada 350 juta carrier (pengidap) didunia. Berdasarkan data yang dimiliki World Health Organization (WHO), badan kesehatan dunia pada tahun 2009, satu dari 12 orang dari seluruh dunia terinfeksi hepatitis $\mathrm{B}$, dengan angka kematian 250 ribu per tahun.

Indonesia menduduki urutan ke 3 di Asia, dibawah Negara Cina, dengan jumlah 123,7 juta dan India 30 Juta. Dengan prevalensi penderita hepatitis B sebesar 5-10\% dari total penduduk, atau 13,5 juta penderita. $^{2}$ Di Indonesia yang imunisasi hepatitis B setiap tahun sekitar $44 \%$ dari sekitar 4,5 juta bayi yang lahir. Artinya setiap tahun ada $36 \%$ bayi yang belum mendapat imunisasi, sehingga dalam 5 tahun menjadi 2 juta anak yang belum mendapat imunisasi hepatitis B. ${ }^{3}$

Data pada tahun 2010 di Kabupaten Ciamis yang terjangkit hepatitis B sebanyak 52 bayi atau $(0,15 \%)$ dari jumlah 34.442 bayi dan yang mendapatkan imunisasi hepatitis B 24.126 bayi atau (70,05\%). Pada tahun 2011 yang terjangkit hepatitis B sebanyak 28 bayi, dan yang mendapatkan imunisasi hepatitis B sebanyak 20.899 bayi $(84,23 \%)$ dari jumlah 24.813 bayi. Sedangkan tahun 2012 sampai dengan bulan Februari yang mendapatkan imunisasi hepatitis B sebanyak 307 bayi (74\%) dari jumlah 4148 bayi. $^{4}$

Berdasarkan hasil laporan dinas kesehatan Kabupaten Ciamis pada tahun 2011 yang terjangkit hepatitis B di daerah Panumbangan sebanyak 3 bayi, Cikoneng 3 bayi, dan Payungsari 2 bayi. Sedangkan untuk cakupan imunisasi di Puskesmas Panumbangan terdapat urutan yang ke 9 dari semua Puskesmas yang berada di Kabupaten Ciamis.

Berdasarkan studi awal tentang pengetahuan ibu terhadap imunisasi hepatitis B dengan sikap ibu dalam mengimunisasikan bayinya di Kecamatan Panumbangan Kabupaten Ciamis masih ada yang kurang respon akan pentingnya imunisasi hepatitis $\mathrm{B}$, sehingga ada anak yang terjangkit hepatitis B sebanyak 0,55\% dan masih adanya ibu yang mempunyai bayi tidak mengimunisasikan hepatitis B ke Puskesmas sekitar 20,9\%.

Berdasarkan latar belakang di atas maka penulis tertarik untuk meneliti hubungan antara tingkat pengetahuan ibu tentang imunisasi hepatitis B dengan sikap ibu mengimunisasikan bayinya di wilayah kerja Puskesmas Kecamatan Panumbangan.

\section{METODE PENELITIAN}

Rancangan Penelitian

Jenis penelitian ini adalah kuantitatif, survei lapangan yang bersifat korelasi yang ingin menjelaskan hubungan pengetahuan dengan sikap ibu tentang imunisasi hepatitis $B$ pada bayi (0-11 bulan) di wilayah kerja Puskesmas Panumbangan tahun 2012.

Metode pendekatan cross-sectional, yaitu jenis penelitian yang mencari hubungan antara variabel bebas(faktor resiko) dan variabel tergantung (efek) yang diobservasi hanya sekali.

\section{Populasi dan Sampel}

Populasi dalam penelitian ini adalah seluruh ibu yang memiliki bayi 1 tahun di wilayah kerja Puskesmas Panumbangan sebanyak 545 orang.

Sampel dalam penelitian ini adalah ibu yang mempunyai bayi 1 tahun,Besar sampel tersebut dibagi ke dalam 6 desa dengan menggunakan stratified random sampling yang akhirnya menjadi random sampling sebanyak 84 orang.

Dengan Rumus Besar sampel yang digunakan dalam penelitian ini adalah :

$$
\begin{aligned}
& \mathrm{N}= \mathrm{N} \\
& 1+\mathrm{N}\left(\mathrm{d}^{2}\right)
\end{aligned}
$$

Keterangan :

$\mathrm{n}=$ Besar Sampel

$\mathrm{N}=$ Besar populasi

$\mathrm{d}=$ Tingkat kepercayaan atau ketepatan yang diinginkan (Notoatmodjo, 2005)

Rancangan penelitian ini adalah cross sectional dengan pendekatan kuantitatif. ${ }^{5}$ 
Data dikumpulkan dari sumber primer. Data dikumpulkan dengan cara membagikan kuesioner kepada ibu yang mempunyai anak 1 tahun. Instrumen penelitian ini menggunakan kuesioner yang telah dibuat oleh peneliti dengan mengacu pada kerangka konsep. Kuesioner akan diberikan pada 84 responden.

Teknik Analisis Data

Analisis Univariat

Dilakukan terhadap tip variabel dari hasil penelitian dengan menggunakan distribusi frekuensi terhadap karakteristik responden dan variabel-variabel penelitian. ${ }^{6}$

Pengolahan data untuk variabel pengetahuan dan sikap ibu dilakukan pelaporan dengan menghitung persentase dari tiap variabel dianalisa, dengan rumus :

$$
\mathrm{P}=\frac{a}{b} \mathrm{X} 100 \%
$$

Keterangan :

$\mathrm{P}=$ Presentase

$a$ = banyaknya jawaban benar

$b=$ Jumlah semua pertanyaan

Kemudian hasil dari perhitungan tersebut dikategorikan dengan menggunakan kaidah dari Arikunto. ${ }^{7}$

Pada variabel Pengetahuan menggunakan kaidah dari Arikunto (2006) ${ }^{7}$ :

- Baik = skor nilai 75-100\% jawaban benar

- Cukup = skor nilai $60-75 \%$ jawaban benar

- Kurang = skor nilai $<60 \%$ jawaban benar. Analisis sikap dengan membagi 2 kategori menurut Skala Guttman,yaitu : ${ }^{8}$

- Sikap positif $>50 \%$ jika menjawab benar

- Sikap negatif $<50 \%$ jika menjawab benar

Analisis Bivariat

Analisis yang dilakukan untuk menguji hubungan antara dua variabel yaitu variabel terikat dan variabel bebas yang diduga mempunyai hubungan atau korelasi. ${ }^{9}$ Analisis bivariat digunakan untuk mencari hubungan antara pengetahuan ibu tentang imunisasi hepatitis B dengan sikap ibu dalam mengimunisasikan bayinya. Uji statistik yang digunakan adalah Chi Square, dengan tingkat kesalahan adalah $\alpha=0,05$. Dengan kriteria jika $\mathrm{p}$ value $<0,05$ maka Ha diterima dan Ho ditolak. Jika $\mathrm{p}$ value $>0,05$ maka Ho diterima dan Ha ditolak artinya tidak ada hubungan antara pengetahuan ibu tentang imunisasi hepatitis B dengan sikap ibu mengimunisasikan bayinya.

\section{HASIL DAN PEMBAHASAN}

1. Karakteristik Responden

a. Umur

Tabel Distribusi Frekuensi Responden Menurut Umur

\begin{tabular}{ccc}
\hline Umur & $F$ & $\%$ \\
\hline$<20$ tahun & 2 & 2,4 \\
$20-35$ tahun & 71 & 84,5 \\
$>35$ tahun & 11 & 13,1 \\
\hline Jumlah & 84 & 100,1
\end{tabular}

Berdasarkan tabel di atas diketahui bahwa ibu yang menjadi responden paling banyak pada rentang $20-35$ tahun $71(84,5 \%)$ responden dan yang paling rendah $<20$ tahun $2(2,4 \%)$ responden.

b. Pekerjaan

\section{Tabel Distribusi Frekuensi Responden Menurut Pekerjaan}

\begin{tabular}{lll}
\hline Pekerjaan & $\mathrm{F}$ & $\%$ \\
\hline $\begin{array}{l}\text { Bekerja } \\
\begin{array}{l}\text { Tidak } \\
\text { bekerja }\end{array}\end{array}$ & 47 & 56,0 \\
\hline Jumlah & 84 & 44,0 \\
\hline
\end{tabular}

Berdasarkan tabel di atas dapat diketahui bahwa ibu yang menjadi responden paling banyak bekerja $37(44,0 \%)$ responden dan yang paling rendah tidak bekerja $37(44,0 \%)$ responden dari 84 responden

c. Pendidikan

\section{Tabel Distribusi Frekuensi Responden Menurut Pendidikan}

\begin{tabular}{lll}
\hline Pekerjaan & F & $\%$ \\
\hline Tidak Tamat SD & 0 & 0,0 \\
Tamat SD & 0 & 0,0 \\
Tamat SLTP & 7 & 8,3 \\
Tamat SLTA & 49 & 58,3 \\
Perguruan Tinggi & 23 & 33,3 \\
\hline Jumlah & 84 & 100,0
\end{tabular}

Berdasarkan tabel diatas menunjukan bahwa ibu yang menjadi responden paling banyak berpendidikan tamatan SLTA 49 (58,3\%) 
responden, dan paling rendah tamatan SD 0 $(0,0 \%)$ dari 84 responden.

Analisis Univariat

a. Tingkat pengetahuan ibu tentang pengertian imunisasi hepatitis B

\section{Tabel distribusi Frekuensi Responden Menurut sikap ibu dalam imunisasi}

\begin{tabular}{ccc}
\hline Pengetahuan & $F$ & $\%$ \\
\hline Rendah & 37 & 44,0 \\
Sedang & 25 & 29,8 \\
Tinggi & 22 & 26,2 \\
\hline Jumlah & 84 & 100,0 \\
\hline
\end{tabular}

Berdasarkan tabel di atas dapat diketahui bahwa sikap ibu yang menjadi responden terhadap imunisasi paling banyak sikap negatif $46(54,8 \%)$ dan paling rendah sikap positif 36 $(45,2 \%)$ responden.

Hasil analisis Bivariat b. Sikap ibu mengimunisasikan bayinya ke Puskesmas

\section{Tabel Distribusi Frekuensi Responden Menurut Sikap ibu dalam imunisasi}

\begin{tabular}{ccc}
\hline Sikap & F & $\%$ \\
\hline Negatif & 46 & 54,8 \\
Positif & 38 & 45,2 \\
\hline Jumlah & 84 & 100,0 \\
\hline
\end{tabular}

Berdasarkan tabel di atas dapat diketahui bahwa sikap ibu yang menjadi responden terhadap imunisasi paling banyak sikap negatif $46(54,8 \%)$ responden dan yang paling rendah sikap positif $36(45,2 \%)$ responden

Tabel Distribusi Responden Menurut Pengetahuan tentang imunisasi dan sikap imunisasi

\begin{tabular}{|c|c|c|c|c|c|c|c|}
\hline \multirow[t]{3}{*}{ Pengetahuan tentang Gizi } & \multicolumn{4}{|c|}{ Sikap Ibu } & \multirow{2}{*}{\multicolumn{2}{|c|}{ Total }} & \multirow[t]{3}{*}{ P Value } \\
\hline & \multicolumn{2}{|c|}{ Negatif } & \multicolumn{2}{|c|}{ Positif } & & & \\
\hline & $\mathrm{n}=46$ & $\%$ & $\begin{array}{c}n=3 \\
8\end{array}$ & $\%$ & $\begin{array}{c}\mathrm{n}=8 \\
4\end{array}$ & $\%$ & \\
\hline Rendah & 26 & $\begin{array}{c}70, \\
3\end{array}$ & 11 & $\begin{array}{c}29, \\
7\end{array}$ & 37 & $\begin{array}{c}100, \\
0\end{array}$ & 0,029 \\
\hline Sedang & 12 & $\begin{array}{c}48, \\
0\end{array}$ & 13 & $\begin{array}{c}52, \\
0\end{array}$ & 25 & $\begin{array}{c}100, \\
0\end{array}$ & \\
\hline Tinggi & 8 & $\begin{array}{c}36 \\
4\end{array}$ & 14 & $\begin{array}{c}63, \\
6\end{array}$ & 22 & $\begin{array}{c}100, \\
0\end{array}$ & \\
\hline
\end{tabular}

Berdasarkan tabel di atas dapat diketahui bahwa terdapat $26(70,3 \%)$ responden yang pengetahuan rendah memiliki sikap negatif terhadap imunisasi. Terdapat $12(48,0 \%)$ responden yang pengetahuan sedang memiliki sikap negatif terhadap imunisasi. Dan terdapat $8(36,4 \%)$ responden yang pengetahuan tinggi memiliki sikap negatif terhadap imunisasi.
Hasil uji statistik didapat nilai $\mathrm{p}=0,029$. Nilai $\mathrm{p}$ tersebut lebih kecil dibandingkan dengan $\alpha$ $(0,05)$ yang berarti hasil uji statistik tersebut adalah Ho ditolak. Pada alpha 5\% dapat disimpulkan ada perbedaan proporsi sikap ibu terhadap imunisasi pada tingkat pengetahuan ibu tentang imunisasi hepatitis B dengan sikap ibu mengimunisasikan bayinya di Kecamatan Panumbangan. 


\section{PEMBAHASAN}

Berdasarkan hasil penelitian tentang hubungan pengetahuan dengan sikap ibu tentang imunisasi hepatitis B pada bayi (0-11 bulan) di wilayah kerja Puskesmas Panumbangan Kecamatan Panumbangan diketahui bahwa tingkat pengetahuan ibu tentang imunisasi hepatitis B paling banyak kategori rendah $37(44,0 \%)$ responden dan yang paling rendah adalah kategori tinggi 22 $(26,2 \%)$ responden. Pada penelitian sikap yang paling banyak adalah kategori sikap negatif 46 $(54,8 \%)$ responden dan yang paling rendah adalah sikap positif $38(45,2 \%)$ responden.

Hasil tersebut dapat diartikan bahwa sebagian besar ibu belum mengetahui mengenai imunisasi hepatitis B tersebut. Banyak faktor yang menyebabkan rendahnya pengetahuan ibu tentang imunisasi hepatitis B antara lain kurangnya penyebarluasan informasi tentang imunisasi secara umum maupun secara khusus masih belum merata, kurangnya ibu dalam menggali tentang informasi pentingnya imunisasi hepatitis $\mathrm{B}$, kurangnya pengetahuan ibu, karena dari hasil penelitian mayoritas ibu adalah tamatan SLTA (47\%) responden, serta kurangnya kunjungan ibu ke Posyandu. Peran petugas kesehatan sangat penting dalam peningkatan pengetahuan ibu terhadap imunisasi hepatitis B.

Pada hasil penelitian ini, ibu yang bekerja lebih banyak $47 \quad(56,0 \%)$ responden dibandingkan dengan ibu yang tidak bekerja, akan tetapi dalam hasil penelitian ini ibu yang bekerja memiliki pengetahuan imunisasi yang masih rendah. Akan tetapi sebagian besar ibu yang bekerja mereka mempunyai sikap positif, berbeda dengan ibu yang tidak bekerja, karena ibu yang tidak bekerja kurang akan informasi dan juga pengalaman dari orang-orang luar.

Selain itu umur juga mempengaruhi tingkat pengetahuan seseorang, dimana jika umur seseorang lebih tua dia akan lebih banyak informasi dan pengalamannya dibandingkan dengan umur yang lebih muda, terbukti dalam penelitian ini dimana jumlah responden terbanyak adalah usia 20-35 tahun sebanyak 71 responden, dimana umur kisaran tersebut mereka masih mencari tahu informasi dan pengalaman mereka pun belum begitu banyak. Pembentukan sikap responden yang negatif terhadap jalannya program imunisasi hepatitis B harus diatasi. Upaya yang dapat dilakukan untuk membentuk sikap adalah dengan peningkatan pemberdayaan tenaga kesehatan untuk memberikan pemahaman tentang penting nya imunisasi hepatitis B kepada masyarakat. Sikap yang positif akan menghasilkan perilaku ibu yang baik dalam pemberian imunisasi hepatitis B. ${ }^{10}$

\section{Hubungan antara pengetahuan ibu tentang imunisasi hepatitis $B$ dengan sikap ibu mengimunisasikan bayinya.}

Berdasarkan penelitian diketahui bahwa terdapat hubungan antara pengetahuan ibu tentang imunisasi hepatitis B dengan sikap ibu mengimunisasikan bayinya di Kecamatan Panumbangan.

Karena semakin tinggi tingkat pengetahuan ibu semakin besar kemungkinan status imunisasi anaknya lengkap.

Pengetahuan ibu akan imunisasi anaknya bukan karena mereka mengerti tentang pesanpesan kesehatan yang disampaikan kepada mereka tetapi karena faktor lain diluar faktor tersebut. Anjuran keluarga terdekat mempengaruhi sikap patuh terhadap pelaksanaan program imunisasi, dan ibu akan menerima program imunisasi jika dianjurkan meskipun tidak terlalu mengerti tujuan dari imunisasi sendiri. ${ }^{11}$

Berkaitan dengan pengetahuan ibu tentang hepatitis B ada beberapa yang berkaitan dengan pengetahuan diantaranya tahu]' (know) diartikan mengingat suatu materi atau ilmu yang berkaitan dengan hepatitis B. Dalam hal ini ibu mengingat kembali sesuatu yang spesifik dari seluruh bahan yang dipelajari atau didapatkan. Selain itu juga ada tahap memahami, aplikasi dan analisis serta sintesis yang berarti tahap dimana telah dapat melakukan evaluasi terhadap kejadian hepatitis B. ${ }^{12}$

Sesuai teori diatas maka ibu memerlukan tahap-tahap tersebut untuk meningkatkan pengetahuan. Peningkatan pengetahuan juga harus diikuti dengan informasi-informasi yang dapat menambah pengetahuan ibu. 
Pengetahuan tentang hepatitis B belum dapat mengubah sikap dan perilaku.

Sikap sendiri merupakan reaksi yang masih tertutup dari seseorang terhadap stimulus atau objek. Sikap belum merupakan tindakan tetapi merupakan salah satu faktor mempermudah untuk terjadinya tindakan. Sikap ibu baik akan menumbuhkan tindakan baik dalam memberikan imunisasi hepatitis B pada bayinya. Sikap yang terbentuk pada individu selalu didasari oleh pengetahuannya tentang masalah yang dihadapinya disamping itu terdapat konsistensi antara pengetahuan dan sikap. Informasi yang diperoleh telah membentuk sikap positif mereka dalam menghadapi masalah kesehatan.

\section{SIMPULAN DAN SARAN}

\section{Simpulan}

Berdasarkan hasil penelitian dan pembahasan Hubungan Pengetahuan dengan Sikap Ibu tentang Imunisasi Hepatitis B pada Bayi (0-11 bulan) di wilayah Kerja Puskesmas Panumbangan tahun 2012, maka disimpulkan :

1. Tingkat Pengetahuan ibu tentang imunisasi Hepatitis B paling banyak kategori rendah yaitu $37(44,0 \%)$ responden.

2. Sikap ibu mengimunisasikan bayinya ke Puskesmas paling banyak sikap negatif 46 $(54,8 \%)$ responden.

3. Terdapat hubungan antara pengetahuan ibu tentang imunisasi hepatitis B dengan sikap ibu mengimunisasikan bayinya di Kecamatan Panumbangan ( nilai $\mathrm{p}=0,029$ $<\alpha=0,05)$.

\section{Saran}

Atas dasar penelitian yang telah dilakukan mengenai hubungan pengetahuan dengan sikap ibu tentang imunisasi hepatitis B pada bayi (011 bulan) di Wilayah Kerja Puskesmas Panumbangan Kabupaten Ciamis,penulis memberikan saran sebagai berikut :

1. Bagi Ibu

Diharapkan Ibu untuk meningkatkan pengetahuannya mengenai hal-hal yang berhubungan dengan kesehatan khususnya dalam pemberian imunisasi hepatitis B dan sering menggali informasi tentang Hepatitis B, serta sering mengikuti kegiatan di Posyandu ataupun penyuluhanpenyuluhan

2. Bagi Peneliti

Dapat mengembangkan variabel yang diteliti tempat, cara dan metode penelitian dari sudut pandang yang berbeda pada bayi, yaitu dengan cara menggali informasi tentang imunisasi hepatitis B dari Puskesmas atau Posyandu.

3. Bagi tenaga kesehatan

Diadakan pelatihan-pelatihan bagi kader terlatih terutama di daerah pedesaan sehingga masyarakat dapat mengakses informasi yang baik dan benar. Dan mengadakan penyuluhan-penyuluhan tentang penting nya pemberian imunisasi hepatitis B kepada setiap desa ataupun Kecamatan.

4. Bagi Puskesmas

Lebih meningkatkan program tentang kesehatan khususnya tentang penting nya hepatitis B dan mengadakan penyuluhanpenyuluhan terutama di desa yang terpencil, serta meningkatkan program kerja posyandu.

\section{DAFTAR PUSTAKA}

1. Zainal S. http://www.imunise.gov.an2009 [cited 201215 march].

2. muhammad. Pedoman Pelaksanaan Imunisasi. Jakarta2010.

3. mahfud. penyebab hepatitis: http://www.kesehatan.123.com//; 2009 [13 Maret 2012].

4. ciamis dk. Data hepatitis B kabupaten Ciamis. 2012.

5. Azwar A, Prihartono J. Metodologi penelitian kedokteran dan kesehatan masyarakat. Batam: Binarupa Akara. 2003.

6. Notoatmodjo S. Metodologi penelitian kesehatan. Jakarta: rineka cipta; 2010.

7. Suharsimi A. Prosedur penelitian suatu pendekatan praktik. Jakarta: Rineka Cipta. 2006.

8. Riduwan M. Skala pengukuran variabelvariabel penelitian. Alfabeta Bandung. 2007. 
9. Arikunto S. Prosedur Penelitian (edisi revisi). Jakarta: Rineka Cipta. 2002.

10. Azwar S. Sikap manusia, teori dan pengukurannya, pustaka pelajar. Jakarta; 2009.

11. Purwanta E. Modifikasi perilaku. Alternatif penanganan anak berkebutuhan khusus Yogyakarta: Pustaka Pelajar. 2012.

12. DepKes R. Keputusan Menteri Kesehatan Republik Indonesia Nomor: 1059. MENKES/IX/2004 Tentang pedoman penyelenggaraan imunisasi, 2005. 